\title{
Efficient Cross-Coupling Reaction of Aryltrifluoroborates and Aroyl Chlorides for the Synthesis of Fluorine Substituted Aromatic Ketones
}

\author{
Mohammed Al-Masum*, Tasfia Islam, Grady Clopton \\ Department of Chemistry, Tennessee State University, Nashville, TN, USA \\ Email: *malmasum@tnstate.edu
}

How to cite this paper: Al-Masum, M., Islam, T. and Clopton, G. (2019) Efficient Cross-Coupling Reaction of Aryltrifluoroborates and Aroyl Chlorides for the Synthesis of Fluorine Substituted Aromatic Ketones. International Journal of Organic Chemistry, 9, 67-72.

https://doi.org/10.4236/ijoc.2019.91006

Received: January 26, 2019

Accepted: March 15, 2019

Published: March 18, 2019

Copyright $\odot 2019$ by author(s) and Scientific Research Publishing Inc. This work is licensed under the Creative Commons Attribution International License (CC BY 4.0).

http://creativecommons.org/licenses/by/4.0/

\begin{abstract}
The direct aroylation of $\mathrm{ArCOPdCl}$ with potassium aryltrifluoroborates establishes a new cross-coupling synthetic tool for the synthesis of various fluorine substituted benzophenones. The new microwave irradiated process is very efficient and produce high yield benzophenone products within minutes.
\end{abstract}

\section{Keywords}

$\mathrm{ArBF}_{3} \mathrm{~K}$, Aroyl Chlorides, Direct Aroylation to Ketones, Minute Reaction

\section{Introduction}

The selective functionalization of potassium aryltrifluoroborates into fluoro-substituted aromatic ketones is an important synthetic task. Fluoro-substituted aromatic ketones are very active pharmaceutical ingredients useful for pharmaceutical application such as anti-inflammatory effects. Introducing fluorine moiety is demanding methodology in medicinal chemistry to adjust binding affinity of small molecules for biological targets and control metabolic reactivity [1] [2]. Fluorinated benzophenones served as starting point for the synthesis of many small benzophenone analogs. Transition metal catalyst, especially palladium, is very popular in organic synthesis because it has a unique ability to activate various organic compounds. This activation can catalyze the formation of new bonds. J. K. Stille first successfully developed the direct cross-coupling reaction of organotin compounds and benzoyl chlorides for benzophenone synthesis [3] [4]. Haddach also has reported a similar cross-coupling reaction by using 
arylboronic acids [5] [6]. In this work, a new reaction method establishes for the direct aroylation reaction of potassium aryltrifluoroborates and $\mathrm{ArCOCl}$ in the presence of $\mathrm{PdCl}_{2}\left(\mathrm{Ph}_{3} \mathrm{P}\right)_{2}$ (Scheme 1$)$.

\section{Results and Discussion}

This direct aroylation reaction combines $\mathrm{PdCl}_{2}\left(\mathrm{Ph}_{3} \mathrm{P}\right)_{2}$ with $\mathrm{K}_{2} \mathrm{CO}_{3}$, as a new catalyst system along with potassium aryltrifluoroborates and fluoro substituted aroyl chlorides in a dry microwave vial under argon. The resulting mixture microwave in 1,4-dioxane at $150^{\circ} \mathrm{C}$ for $20 \mathrm{~min}$ and obtained high yield products of various fluoro substituted benzophenones. Recently, new synthetic methods for crotonophenones by cross coupling of potassium allyl trifluoroborate with aroyl chlorides, and chalcones from potassium styryl trifluoroborates and aroyl chlorides have been established [7] [8]. In both cases, $\mathrm{PdCl}_{2}$ ( $\mathrm{d}^{\mathrm{t} b p f}$ ) complex has shown remarkable catalyst effect for successful transformations (Scheme 2). In line with those findings, it has assumed that same catalyst system would work for cross coupling of aryl trifluoroborates with aroyl chlorides. Surprisingly, no desired benzophenones observed as major products.

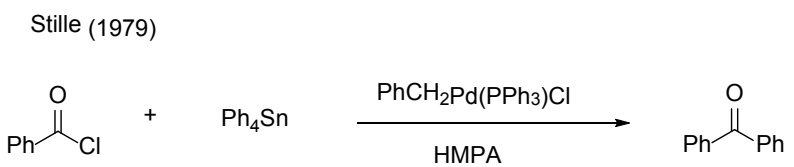

$$
\text { Haddach (2008) }
$$

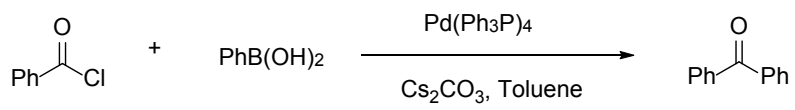

$$
\begin{aligned}
& \text { This work }
\end{aligned}
$$

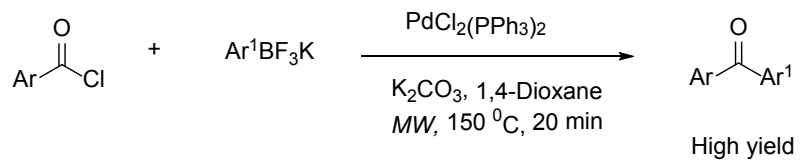

Scheme 1. Aryltrifluoroborates for aroylation reactions.

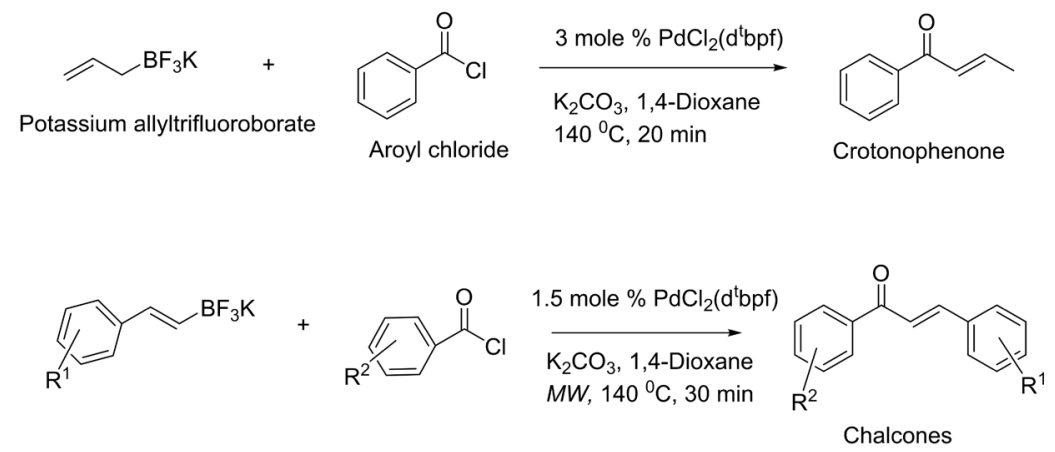

Scheme 2. Organotrifluorborates and direct aroylation to crotonophenones and chalcones. 
After further investigation with several palladium complexes and bases to find a suitable conditions for aroylation of potassium aryltrifluoroborates under microwave irradiation, the effective catalyst effect of $\mathrm{PdCl}_{2}\left(\mathrm{Ph}_{3} \mathrm{P}\right)_{2}$ complex has been observed and successfully synthesize series of fluoro-substituted aromatic ketones in high yields.

The results summarize in Figure 1. It appears that 1,4-dioxane as the solvent system gave successful results in cross-coupling reaction. The biggest challenge of this project was the formation of homo-coupling product instead of cross coupling. Often times the $\mathrm{ArBF}_{3} \mathrm{~K}$ reacts with itself giving biphenyl as homo coupling product that observed in GC-MS. This problem is mostly overcome by applying 3 mole $\% \mathrm{PdCl}_{2}\left(\mathrm{Ph}_{3} \mathrm{P}\right)_{2}$ as catalyst.

The mechanism for the direct cross-coupling reaction of potassium organotrifluoroborates and benzoyl chlorides proposes in Scheme 3. The catalytic cycle involves the palladium insertion by oxidative addition followed by ligand exchange with the $\mathrm{K}_{2} \mathrm{CO}_{3}$. Then occurring transmetallation of organoboron species to the organopalladium, followed by forming the desired cross coupling product by reductive elimination.

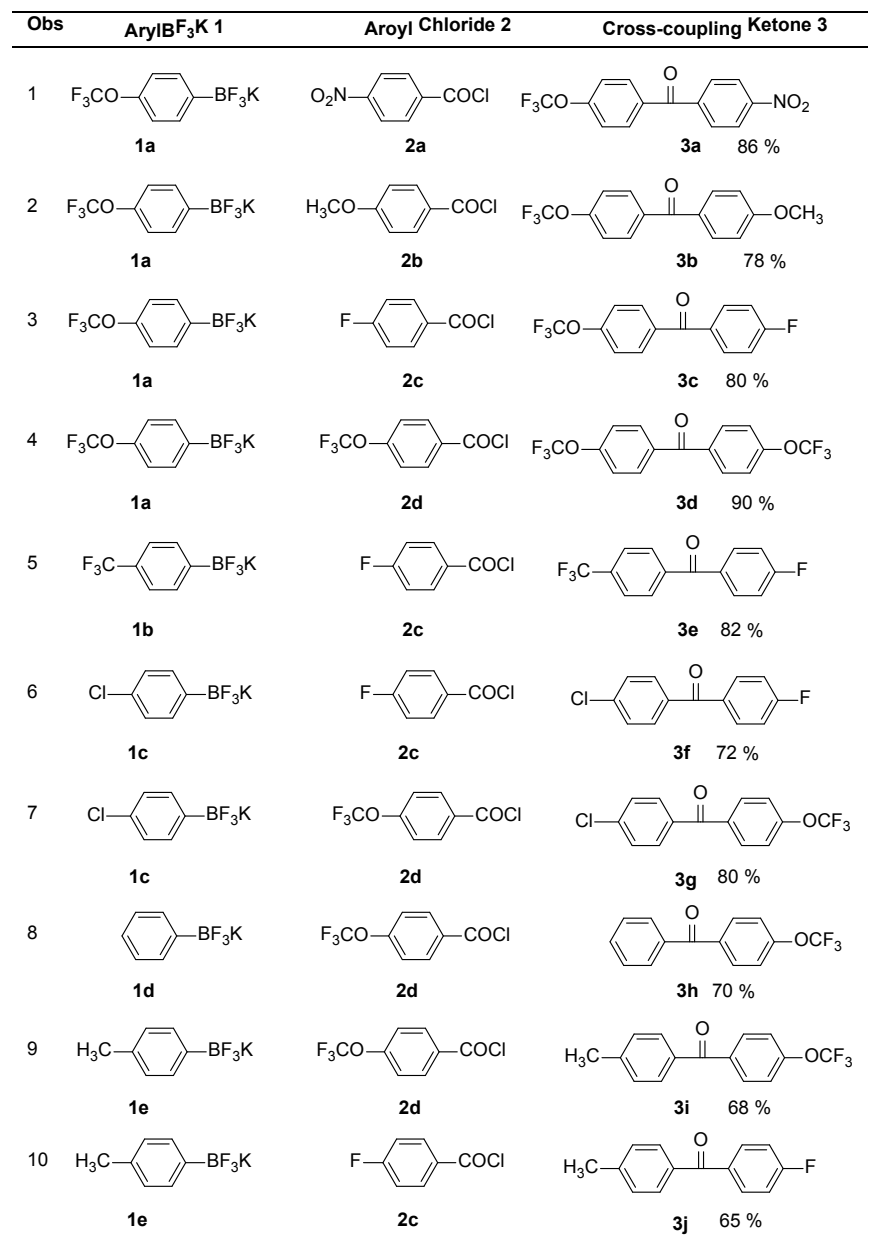

Figure 1. Cross-coupling of $\mathrm{AryIBF}_{3} \mathrm{~K}$ and $\mathrm{ArCOPdCl}$ for Fluorinatedketoones ${ }^{\mathrm{a}}$. ${ }^{\mathrm{a}}$ Isolated products separated by silica gel chromatography. 


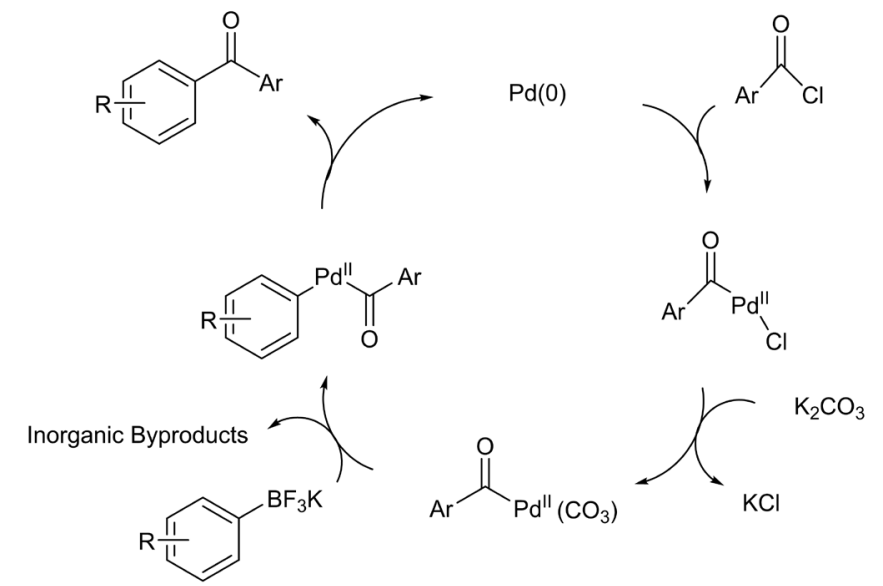

Scheme 3. Catalytic cycle for direct aroylation of $\mathrm{ArylBF}_{3} \mathrm{~K}$.

\section{Conclusions}

This work demonstrates the novel application of potassium aryltrifluoroborates with aroyl chlorides for cross coupling reaction. A new catalyst system is established. The application of microwave heating drastically reduced the amount of time to 20 minutes. Usually this type of coupling requires 8 - 24 hours heating in conventional heating system. The direct aroylation of potassium aryltrifluoroborates is great addition to the direct aroylation of potassium styryltrifluoroborates, potassium allyltrifluoroborate, and potassium crotyltrifluoroborate.

\section{Experimental}

\section{Synthesis of aryl trifluoroborates $\left(\mathrm{BF}_{3} \mathrm{~K}\right)$; the starting material}

$\mathrm{ArBF}_{3} \mathrm{~K}$ is synthesized from boronic acid. In a typical synthesis, in a round bottom flask with a stirrer, about $20 \mathrm{~mL}$ of methanol was added to $20 \mathrm{mmol}$ of boronic acid. This mixture was completely dissolved in the methanol. The solution was clear. On a separate small beaker, $120 \mathrm{mmol}$ (about $9.36 \mathrm{~g}$ ) potassium hydrogen fluoride $\left(\mathrm{KHF}_{2}\right)$ was dissolved in $20 \mathrm{~mL}$ of DI water. This $\mathrm{KHF}_{2}$ solution then added to the methanol mixture while the mixture was stirring vigorously. This resulting thick mixture was on vigorous starring for 4 hours. The solvent in the mixture dried up by using rotary evaporator followed by high vacuo for complete dry. To remove excess $\mathrm{KHF}_{2}$ from the crude product, $250 \mathrm{~mL}$ of boiled acetone added into the mixture. The clear liquid part of the mixture then filtered through sintered funnel and the filtrate evaporated in a rotary evaporator until it was completely dry. To recrystallize the mixture, the product was dissolved in minimum amount of acetonitrile $\left(\mathrm{CH}_{3} \mathrm{CN}\right)$ followed by adding diethyl ether until solid crystal formed. The crystallized solid potassium aryltrifluoroborate product was collected in high yields.

Synthesis of 4-fluoro-4'-trifluoromethylbenzophenone is arepresentative one.

A small dry microwave reaction vial loaded with $0.5 \mathrm{mmol}$ of potassium (4-trifluoromethyl)phenyltrifluoroborate, $2 \mathrm{mmol}$ of $\mathrm{K}_{2} \mathrm{CO}_{3}$ and $0.015 \mathrm{mmol}$ of $\mathrm{PdCl}_{2}\left(\mathrm{Ph}_{3} \mathrm{P}\right)_{2}(11.0 \mathrm{mg})$. The vial was capped with air-tight septum followed by 
flushing with argon. The palladium is very sensitive to air. It was made sure that this catalyst was added at the end to prevent any air exposer. $121.0 \mu \mathrm{L}$ of 4-fluoroaroyl chloride $(1.0 \mathrm{mmol})$ was transferred to the mixture via syringe. After adding $5.0 \mathrm{~mL}$ of 1,4-Dioxane as solvent, the resulting mixture was stirred at room temperature for couple of minutes and then inserted the vial into microwave system and heated at $150^{\circ} \mathrm{C}$ for $20 \mathrm{~min}$. The crude product was filtered through celite pad by using ethyl acetate. After examining the GC-MS, $10 \mathrm{~g}$ of silica gel was added to the filtrate and evaporated the solvent by rotary evaporator. The compound adsorbed in silica gel was then transferred into silca gel column for chromatography.

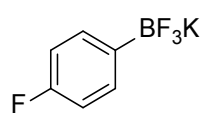

$1 b$

Potassium (4-fluoro)phenyltrifluoroborate<smiles>O=C(Cl)c1ccc(C(F)(F)F)cc1</smiles>
4-trifluoromethyl-aroyl chloride

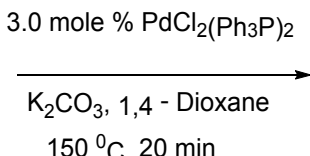

$150{ }^{\circ} \mathrm{C}, 20 \mathrm{~min}$

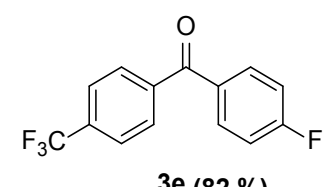

4-fluoro-4'-trifluoromethylbenzophenone

\section{Data for the products shown in Figure 1}

Compound 3a, ${ }^{1} \mathrm{HNMR}\left(\mathrm{CDCl}_{3}, 400 \mathrm{MHz}\right) \delta 8.31-7.19$ (m, 8H); ${ }^{13} \mathrm{CNMR}$ $\left(\mathrm{CDCl}_{3}, 100 \mathrm{MHz}\right) \delta 193.2,142.3,134.4,132.1,130.6,123.7,120.4 ;{ }^{19} \mathrm{FNMR}$ $\left(\mathrm{CDCl}_{3}, 400 \mathrm{MHz}\right) \delta-57.7$.

Compound 3b, ${ }^{1} \mathrm{HNMR}$ (Acetone- $\left.\mathrm{d}_{6}, 400 \mathrm{MHz}\right) \delta 8.12-7.07(\mathrm{~m}, 8 \mathrm{H}), 3.91(\mathrm{~s}$, $3 \mathrm{H}$ ); ${ }^{13} \mathrm{CNMR}$ (Acetone- $\left.\mathrm{d}_{6}, 100 \mathrm{MHz}\right) \delta 193.9,167.3,165.8,164.4,163.1$, 138. 1 , 131.1, 123.7, 121.4, 1114.5, 56.0; ${ }^{19} \mathrm{FNMR}$ (Acetone- $\left.\mathrm{d}_{6}, 400 \mathrm{MHz}\right) \delta$-58.5.

Compound 3c, ${ }^{1} \mathrm{HNMR}\left(\mathrm{CDCl}_{3}, 400 \mathrm{MHz}\right) \delta 7.78-7.07(\mathrm{~m}, 8 \mathrm{H})^{13} \mathrm{CNMR}$ $\left(\mathrm{CDCl}_{3}, 100 \mathrm{MHz}\right) \delta 193.7,167.2,163.8,152.1,135.7,133.2,131.7,120.8,116.1$, ${ }^{19} \mathrm{FNMR}\left(\mathrm{CDCl}_{3}, 400 \mathrm{MHz}\right) \delta-57.6,105.2$.

Compound 3d, ${ }^{1} \mathrm{HNMR}\left(\mathrm{CDCl}_{3}, 400 \mathrm{MHz}\right) \delta 7.87-7.33(\mathrm{~m}, 8 \mathrm{H}){ }^{13} \mathrm{CNMR}$ $\left(\mathrm{CDCl}_{3}, 100 \mathrm{MHz}\right) \delta 193.6,152.3,135.3,131.9,120.3,29.7,{ }^{19} \mathrm{FNMR}\left(\mathrm{CDCl}_{3}, 400\right.$ $\mathrm{MHz}) \delta$-57.6.

Compound 3e, ${ }^{1} \mathrm{HNMR}$ (Acetone- $\left.\mathrm{d}_{6}, 400 \mathrm{MHz}\right) \delta 8.12$ - $7.22(\mathrm{~m}, 8 \mathrm{H}$ ); ${ }^{13} \mathrm{CNMR}$ (Acetone- $\left.\mathrm{d}_{6}, 100 \mathrm{MHz}\right) \delta 194.3,167.8,166.8,165.3,133.8,133.2,131.2$, 126.4, 116.4; ${ }^{19}$ FNMR (Acetone- $\left.\mathrm{d}_{6}, 400 \mathrm{MHz}\right) \delta-63.4,-107.1$.

Compound 3f, ${ }^{1} \mathrm{HNMR}$ (Acetone- $\left.\mathrm{d}_{6}, 400 \mathrm{MHz}\right) \delta 7.89$ - $7.33(\mathrm{~m}, 8 \mathrm{H}$ ); ${ }^{13} \mathrm{CNMR}$ (Acetone-d $\left.\mathrm{d}_{6}, 100 \mathrm{MHz}\right) \delta 194.1,167.5,165.0,139.0137 .1,133.6,132.3$, 129.6, 16.5; ${ }^{19} \mathrm{FNMR}$ (Acetone-d $\left.{ }_{6}, 400 \mathrm{MHz}\right) \delta-107.9$.

Compound 3g, ${ }^{1} \mathrm{HNMR}\left(\mathrm{CDCl}_{3}, 400 \mathrm{MHz}\right) \delta 7.58$ - 7.28) (m, 8H), ${ }^{13} \mathrm{CNMR}$ $\left(\mathrm{CDCl}_{3}, 100 \mathrm{MHz}\right) \delta 194.2,148.8,138.7,138.2,133.8,129.0,128.3,121.3,{ }^{19} \mathrm{FNMR}$ $\left(\mathrm{CDCl}_{3}, 400 \mathrm{MHz}\right) \delta-57.8$. 
Compound 3h, ${ }^{1} \mathrm{HNMR}\left(\mathrm{CDCl}_{3}, 400 \mathrm{MHz}\right) \delta 7.79-7.22(\mathrm{~m}, 8 \mathrm{H}),{ }^{13} \mathrm{CNMR}$ $\left(\mathrm{CDCl}_{3}, 100 \mathrm{MHz}\right) \delta 195.2,152.1,137.1,135.8,131.9,129.9,128.4,120.2,{ }^{19} \mathrm{FNMR}$ $\left(\mathrm{CDCl}_{3}, 400 \mathrm{MHz}\right) \delta-57.6$.

Compound 3i, $\left.{ }^{1} \mathrm{HNMR}\left(\mathrm{CDCl}_{3}, 400 \mathrm{MHz}\right) \delta 8.19-7.30(\mathrm{~m}, 8 \mathrm{H}), 2.459 \mathrm{~s}, 3 \mathrm{H}\right)$; ${ }^{13} \mathrm{CNMR}\left(\mathrm{CDCl}_{3}, 100 \mathrm{MHz}\right)$ 195.0, 170.8, 153.2, 132.2, 131.8, 130.2, 129.1, 120.2, 21.6; ${ }^{19} \mathrm{FNMR}\left(\mathrm{CDCl}_{3}, 400 \mathrm{MHz}\right) \delta-57.6$.

Compound 3j, ${ }^{1} \mathrm{HNMR}$ (Acetone- $\mathrm{d}_{6}, 400 \mathrm{MHz}$ ) $\delta 7.36-6.91(\mathrm{~m}, 8 \mathrm{H}), 1.96(\mathrm{~s}$, $3 \mathrm{H}) ;{ }^{13} \mathrm{CNMR}$ (Acetone- $\left.\mathrm{d}_{6}, 100 \mathrm{MHz}\right) \delta 184.5,134.2,124.6,122.8,122.7,120.2$, $119.8,106.1,11.5$.

Compound 3k, ${ }^{1} \mathrm{HNMR}\left(\mathrm{CDCl}_{3}, 400 \mathrm{MHz}\right) \delta 7.83$ - $6.97(\mathrm{~m}, 8 \mathrm{H}), 3.90(\mathrm{~s}, 3 \mathrm{H})$; ${ }^{19} \mathrm{FNMR}\left(\mathrm{CDCl}_{3}, 400 \mathrm{MHz}\right) \delta-57.6$ [product 3k from potassium (4-methoxy) phenyltrfluoborate and 4-trifluoromethoxy benzoyl chloride was not added in Figure 1 due to limited space].

\section{Conflicts of Interest}

The authors declare no conflicts of interest regarding the publication of this paper.

\section{References}

[1] Woydziak, Z.R., Fu, L. and Peterson, B.R. (2012) Synthesis of Fluorinated Benzophenones, Xanthones, Acridones, and Thioxanthones by Iterative Nucleophilic Aromatic Substitution. The Journal of Organic Chemistry, 77, 473-481. https://doi.org/10.1021/jo202062f

[2] Belluti, F., Simone, A.D., Tarozzi, T., Bartolini, M., Djemil, A., Bisi, A.S., Gobbi, S., Montanari, S., Cavalli, A., Andrisano, V., Bottegoni, G. and Rampa, A. (2014) Fluorinated Benzophenone Derivatives: Balanced Multipotent Agents for Alzheimer's Disease. European Journal of Medicinal Chemistry, 78, 157-166. https://doi.org/10.1016/j.ejmech.2014.03.042

[3] Stille, J.K. (1978) A General, Selective, and Facile Method for Ketone Synthesis from Acid Chlorides and Organotin Compounds Catalyzed by Palladium. Journal of the American Chemical Society, 100, 3636-3638. https://doi.org/10.1021/ja00479a077

[4] Labadie, J.W. and Stille, J.K. (1983) Mechanism of the Palladium-Catalyzed Couplings of Acid Chlorides with Organotin Reagents. Journal of the American Chemical Society, 105, 6129-6137. https://doi.org/10.1021/ja00357a026

[5] Haddach, M. and McCarthy, J.R. (1999) A New Method for the Synthesis of Ketones: The Palladium-Catalyzed Cross-Coupling of Acid Chlorides with Arylboronic Acids. Tetrahedron Letters, 40, 3109-3112. https://doi.org/10.1016/S0040-4039(99)00476-1

[6] Cho, C.S. (2008) A Recyclable Palladium Catalysis in Cross-Coupling Reactions between Aroylchlorides and Sodium Tetraphenylborate. Catalysis Communications, 9, 2261-2263. https://doi.org/10.1016/j.catcom.2008.05.013

[7] Al-Masum, M. and Liu, K. (2011) A New Organic Transformation by Introduction of Crotyl/Allyltrifluoroborates in Cross-Coupling Reaction with Aroyl Chlorides. Tetrahedron Letters, 52, 5090-5093. https://doi.org/10.1016/j.tetlet.2011.07.107

[8] Al-Masum, M. and Wai, E.Ng. (2011) Palladium-Catalyzed Direct Cross-Coupling of Potassium Styryltrifluuoroborates and Benzoyl Chlorides-A One Step Method for Chalcone Synthesis. Tetrahedron Letters, 52, 1008-1010. https://doi.org/10.1016/j.tetlet.2010.12.085 